\title{
O życiu i działalności naukowej Eugenii Piaseckiej-Zeylandowej ${ }^{1}$
}

\section{About Eugenia Piasecka-Zeylandowa, her life and investigation}

\author{
Henryk Siciński
}

\author{
Ostrów Wielkopolski
}

\begin{abstract}
Streszczenie: Artykuł przedstawia życie i działalność badawczą Eugenii Piaseckiej-Zeylandowej, wybitnej znawczyni problematyki prątka gruźlicy, docent Uniwersytetu Poznańskiego. Dla historii medycyny szczególną wartość mają informacje o jej ostatnich latach życia.
\end{abstract}

\begin{abstract}
The article describes Eugenia Piasecka-Zeylandowa, her life and research on the tubercle bacillus. Piasecka-Zeylandowa, reader of Poznan University, was an outstanding expert of issues of tuberculosis and BCG vaccination. This article provides information on her last years.
\end{abstract}

Słowa kluczowe: Eugenia Piasecka-Zeylandowa, gruźlica

Keywords: Eugenia Piasecka-Zeylandowa, tuberculosis

\section{Dzieciństwo i młodość}

Eugenia Jadwiga Piasecka-Zeylanowa urodziła się 25 lutego 1899 r. w Krakowie. Była córką Eugeniusza Piaseckiego (ur. w 1872 r. we Lwowie), późniejszego profesora Uniwersytetu Poznańskiego, twórcy Studium Wychowania Fizycznego przy Wydziale Lekarskim UP² oraz Gizeli Marii Szelińskiej (ur. w 1877 r. w Krakowie) pochodzącej

\footnotetext{
1 Artykuł stanowi recenzowaną wersję wystapienia podczas Konferencji Naukowej „Gruźlica - dawne doświadczenia, obecne osiagnięcia i zagrożenia" - Obra k/Wolsztyna 19 maja 2018 r.

2 Prof. Eugeniusz Witold Piasecki był synem nauczyciela gimnastyki Wenantego Piaseckiego - twórcy towarzystwa Gimnastycznego "Sokół” we Lwowie, które było zaczątkiem organizacji paramilitarnych u progu rodzacej się niepodległości. E. Piasecki po ukończeniu studiów medycznych na UJ powrócił do Lwowa, gdzie zorganizował przy IV Gimnazjum Klub Gimnastyczno-Sportowy, który przekształcił się w 1907 r. w klub sportowy Pogoń Lwów. Od 1909 r. wykładał teorię wychowania fizycznego i higieny szkolnej na stanowisku docenta Uniwersytetu Jana Kazimierza we Lwowie. Wśród wielu aktywności społecznych był też harcmistrzem Rzeczypospolitej i współtwórca Karpackiego Towarzystwa Narciarzy. W 1919 r. został profesorem tworzącego się Uniwersytetu Poznańskiego, gdzie zorganizował Katedrę Teorii Wychowania Fizycznego (w 1919 r.) oraz Studium Wychowania Fizycznego przy Wydziale Lekarskim UP. Opublikował jako pierwszy w świecie prace na temat gimnastyki niemowląt. Był ekspertem Ligii Narodów. Zmarł 17 lipca 1947 r. pod Cieplicami, pochowany jest na Cmentarzu Górczyńskim w Poznaniu. (wg noty w Wikipedii wraz z przypisami i bibliografia).
} 
ze znanej i rozległej rodziny żydowskiej Silberfeld-Krasnik². Eugenia była najstarsza z pięciorga rodzeństwa, rok młodszy brat Stanisław był w okresie międzywojennym założycielem tygodnika literacko-artystycznego „Prosto z Mostu”"4.

Eugenia Piasecka-Zeylandowa po kilku latach nauki w gimnazjum we Lwowie kontynuowała ją od 1914 r. w Zakopanem, kończąc w 1917 r. maturą. Rozpoczęła studia medyczne na Uniwersytecie Jagiellońskim, a w latach 1918-1919 pracowała w laboratorium chemiczno-bakteriologicznym Szpitala Czerwonego Krzyża w Zakopanem. W 1919 r. zapisała się na studia chemiczne (Wydział Lekarski jeszcze nie powstał) na Uniwersytecie Poznańskim, gdzie jej ojciec objął Katedrę Teorii Wychowania Fizycznego i Higieny Szkolnej. W 1920 r. podczas wojny polsko-bolszewickiej przez 4 miesiące pracowała jako siostra Czerwonego Krzyża w pociagu sanitarnym.

Studia medyczne rozpoczęte na UJ, od 1921 r. kontynuowała na UP kończąc je w 1924 r. jako doktor wszech nauk lekarskich. Podczas studiów była demonstratorka przy Katedrze Chemii Fizycznej, a pod ich koniec zajmowała stanowisko zastępcy młodszego asystenta w Zakładzie Anatomii Patologicznej UP. Po studiach rozpoczęła pracę w Zakładzie Mikrobiologii Lekarskiej UP na stanowisku asystentki, a następnie od 1925 r. adiunkta.

16 czerwca 1926 r. w kościele p.w. Matki Boskiej Bolesnej na poznańskim Łazarzu zawarła ślub z doktorem Januszem Zeylandem, z którym już od dłuższego czasu współpracowała w Zakładzie Mikrobiologii Lekarskiej ${ }^{5}$. Zamieszkali przy ul. Ratajczaka 11 (dziś numer 26) w podwórzu6

Wraz z mężem wyjechała do Paryża, gdzie spędziła kilka tygodni w pracowni prof. Jana Danysza i prof. Alberta Calmette w Instytucie Pasteura, poznając francuskie metody pracy mikrobiologicznej. Pod koniec pobytu Zeylanowie otrzymali w darze

3 Rodzina Silberfeld-Krasnik z krakowskiego Kazimierza datująca swoich protoplastów od drugiej połowy 18 wieku (Wikipedia.pl).

4 Stanisław Piasecki był rok młodszym bratem Eugenii, urodzony we Lwowie w 1900 r. brał udział w walkach o Lwów w 1918-19 r. a rok później w wojnie polsko-bolszewickiej. Studiował we Lwowie architekturę a następnie w Poznaniu - prawo. Był członkiem Związku Akademickiego Młodzież Wszechpolska. Był założycielem w 1935 r. tygodnika literacko- artystycznego o wyraźnie narodowym profilu, z którym współpracowali: Karol Irzykowski, Zofia Kossak, Kazimiera Iłłakowiczówna, ale również : Witold Gombrowicz, Maria Pawlikowska- Jasnorzewska, Józef Czechowicz, Jerzy Andrzejewski i Konstanty Ildefons Gałczyński. Na kilka lat przed wojną tygodnik stal się wyraźnie propagatorem idei antysemickich. Po ochotniczym udziale w kampanii wrześniowej Stanisław Piasecki włączył się w Warszawie do konspiracji Stronnictwa Narodowego , współredagował podziemne pismo „Walka” czerpiąc fundusze z prowadzonej restauracji „Arkadia” mieszczącej się w gmachu Filharmonii Narodowej. Żoną Stanisława Piaseckiego była córka gen. Antoniego Religioniego, śpiewaczka operowa. W grudniu 1940 r. został aresztowany, osadzony na Pawiaku i po brutalnym śledztwie rozstrzelany 12 czerwca w Palmirach w Puszczy Kampinoskiej. Wg noty zawartej w Wikipedii. Zachował się odpis świadectwa ślubu Piaseckich (kopia w posiadaniu autora).

5 Archiwum Szpitala Kubalonka w Istebnej (dalej: ASK), Akta personalne E. Piaseckiej-Zeylandowej, Własnoręcznie podpisane curriculum vitae E. Piaseckiej-Zeylandowej z 15 sierpnia 1946 r. (kopia w posiadaniu autora).

6 Uniwersytet Poznański. Spis wykładów i skład na rok akademicki 1932/33, Poznań 1932, s. 150. 
od Calmette niechorobotwórczy szczep pratków gruźlicy, znany jako Bacille Calmette-Guérin (BCG) i używany do produkcji szczepionki .

\section{Badania nad gruźlicą}

Otrzymany w Paryżu szczep bakterii pozwolił Zeylandom na badanie szczepionki BCG i zorganizowanie w 1928 roku w Poznaniu pierwszego w Polsce punktu szczepień przeciwgruźliczych. $\mathrm{W}$ tym samym roku Piasecka-Zeylandowa uczestniczyła wraz z mężem w konferencji w Instytucie Pasteura w Paryżu, podczas której prof. Albert Calmette wykładając o bakterii gruźlicy przywołał komunikat Zeylandów o przenikaniu prątków BCG przez ścianę przewodu pokarmowego. W tym samym roku na Zjeździe Przeciwgruźliczym w Poznaniu Janusz Zeyland przedstawił napisany wraz z Eugenia referat o szczepieniach przeciwgruźliczych sposobem Calmette'a. W kolejnych latach na tematycznych konferencjach w Wilnie i w Oslo Zeylandowie prezentowali wyniki wspólnej pracy naukowej nad szczepionką BCG. W 1930 r. Akademia Lekarska w Paryżu przyznała obojgu uczonym nagrodę im. Pannetiera za ich wkład w badania prowadzone w Instytucie Pasteura nad szczepionka przeciw gruźlicy. W 1931 r. oboje otrzymali srebrny medal UP.

W 1935 r. Piasecka-Zeylandowa opublikowała podręcznik „Bakteriologiczne rozpoznawanie gruźlicy u ludzi" i odbyła podróż naukową do Anglii, Holandii i Niemiec, by zwiedzić placówki zajmujące się gruźlica. W 1936 r. została habilitowana na Wydziale Lekarskim Uniwersytetu im. Józefa Piłsudskiego w Warszawie w zakresie mikrobiologii lekarskiej, po czym jej prawo wykładania zostało przeniesione na $\mathrm{Wy}$ dział Lekarski UP.

W 1938 r. Uniwersytet Poznański przyznał obojgu uczonym stypendium naukowe im. Marszałka Piłsudskiego na podróż do Stanów Zjednoczonych Ameryki Północnej, z którego zrezygnowali wobec jawnych przygotowań Niemców do drugiej wojny światowej.

W marcu 1940 r. niemiecki okupant poprzez obóz przejściowy przy ul. Głównej w Poznaniu przesiedlił Zeylandów do Warszawy, gdzie początkowo oboje pracowali w Szpitalu Skarbowców na Lesznie, a następnie, po włączeniu tego szpitala w obręb getta, w Szpitalu Wolskim. Tam prof. Janusz Zeyland zorganizował, a następnie prowadził pierwszy w Polsce Oddział Przeciwgrú́liczy dla Dzieci, natomiast Eugenia Piasecka- Zeylandowa prowadziła w laboratorium szpitalnym dalsze prace badawcze nad prątkiem gruźlicy przygotowując rozdział „O prątku gruźlicy", w 1948 r. zamieszczony w książce „Mikrobiologia lekarska” pod redakcją Feliksa Przesmyckiego. Ponadto w czasie okupacji prowadziła wykłady, ćwiczenia i egzaminy na tajnym Uniwersytecie Ziem Zachodnich, który stanowił kontynuację Uniwersytetu Poznańskiego.

7 K. Surdyk, M. Knapowska-Niziołek, Żona w cieniu męża, „Fakty UMP” 2009, nr 1, s. 17-18. 


\section{Ostatnie lata życia}

Po śmierci męża, zamordowanego przez Niemców strzałem w czoło 5 września 1944 r. w gabinecie dyrektora Szpitala Wolskiego, oraz po upadku Powstania Warszawskiego przebywała od ostatniego dnia tego miesiąca w Podkowie Leśnej, a następnie od 29 stycznia 1945 r. w Makowie Podhalańskim8. Od 1 lutego 1945 r. doc. Eugenia Piasecka-Zeylandowa była zarejestrowana w wykazie pracowników Uniwersytetu Jagiellońskiego. W kwesturze uczelni odnotowano, że do końca 1945 r. pobierała uposażenie wraz z dodatkiem naukowym. Poświadcza to pismo wystawione przez kwesturę 13 grudnia $1946 \mathrm{r}$.

Wśród dokumentów, do których udało się autorowi dotrzeć, znajduje się okólnik Wydziału Lekarskiego UP z 18 kwietnia 1945 r., zawierający wykaz osób powiadomionych o posiedzeniu Rady Wydziału w dniu 21 tego miesiąca. Wśród nich była doc. Eugenia Piasecka-Zeylandowa. Okólnik podpisał dziekan, prof. Witold Kapuściński, co wskazuje na to, że spodziewał się jej obecności, ale w kolejnych sprawozdaniach z posiedzeń Rady Wydziału nazwisko jej już się nie powtórzyło. Natomiast w „Składzie Uniwersytetu w roku akademickim 1947/48", który obejmował tylko pracowników UP, odnotowano ja jako przebywająca w Krakowie?.

Trudno odtworzyć, co wtedy się z nią działo. Istnieje podanie Piaseckiej-Zeylandowej z 15 sierpnia 1946 r. o zatrudnienie na stanowisku kierownika Laboratorium Bakteriologicznego w Wojewódzkim Zakładzie Leczniczo-Wychowawczym w Istebnej, poparte pismem dyrektora Zakładu dra Włodzimierza Leśniewskiego, datowanym na następny dzień. Decyzję o przyjęciu "tymczasowo do pracy” podją 11 listopada tego roku ówczesny wicewojewoda śląsko-dąbrowski płk. Jerzy Ziętek. Prawdopodobnie zgłosiła się do pracy w grudniu 1946 r., bowiem fakt zamieszkania w Istebnej i to, że przyjechała tam z Krakowa odnotowano w Biurze Meldunkowym Urzędu Gminy pod datą 13 grudnia $1946 \mathrm{r}$.

W przechowywanej w Istebnej teczce personalnej Eugenii Piaseckiej-Zeylandowej znajduje się pismo z 2 listopada 1948 r., w którym Klinika Położnictwa i Chorób Kobiecych UJ powiadomiła Zakład w Istebnej o leczeniu w niej doc. Piaseckiej-Zeylandowej. Dla niektórych urzędów problemem okazało się wypłacanie poborów pracownikowi na długotrwałym zwolnieniu. Zachowała się korespondencja dyrektora Departamentu Kadr Ministerstwa Zdrowia Z. Branowitzera z 22 stycznia 1948 r., który polecał utrzymać zatrudnienie doc. E.Piaseckiej-Zeylandowej i „wypłacać jej pobory w dotychczasowej wysokości".

Szczególny charakter miała tajemnicza decyzja Wydziału Finansowego Prezydium Wojewódzkiej Rady Narodowej w Poznaniu z 17 marca 1952 r. zezwalająca doc. Eugenii Piaseckiej-Zeylandowej na podstawie "dekretu o zobowiązaniach podatkowych z tytułu podatku od wzbogacenia wojennego" na spłatę kwoty $19780 \mathrm{zł} \mathrm{w}$ ratach po 100 zł do marca 1955 r. Decyzję uchylono 22 marca 1952 r.

ASK, Akta personalne E. Piaseckiej-Zeylandowej.

Skład Uniwersytetu w roku akademickim 1947/48, Poznań 1948, s. 122. 
W tym czasie musiała być już poważnie chora, bo 10 października 1952 r. dyrektor Szpitala Kubalonka dr Zygmunt Dadlez poinformował Departament Walki z Gruźlicą Ministerstwa Zdrowia, że „doc. E. Zeylandowa, która mimo że nie pracuje w tut. Zakładzie już od 1950 r. z powodu ciężkiej choroby (sclerosis multiplex) otrzymuje... pełne wynagrodzenie + dodatek zakaźny oraz mieszkanie i wyżywienie". Dyrektor równocześnie zaznaczył, że w budżecie Zakładu w Istebnej na 1953 r. nie został przewidziany etat dla doc. E. Zeylandowej: „,...równocześnie nadmieniam, że stan zdrowia doc. Zeyland pogarsza się i być może będzie musiała być umieszczona w oddziale specjalistycznym"10 ${ }^{\prime 10}$ W tej sytuacji Minister Zdrowia wystapił do Premiera o przyznanie wyjatkowego zaopatrzenia dla doc. E. Piaseckiej-Zeylandowej.

Wybitna badaczka prątka gruźlicy zmarła w Istebnej w dniu 5 stycznia 1953 r. Spoczywa wraz z mężem - prof. Januszem Zeylandem - na cmentarzu Jeżyckim przy ul. Nowina w Poznaniu.

Autor tego opracowania nie ustaje w poszukiwaniu dokumentów związanych z osobami obojga Zeylandów świadom tego, że wiele z nich zostało bezpowrotnie utraconych w działaniach wojennych.

Wykaz źródeł:

Archiwum Szpitala Kubalonka w Istebnej, Akta personalne E. Piaseckiej-Zeylandowej.

Wykaz literatury:

1. Skład Uniwersytetu w roku akademickim 1947/48, Poznań 1948.

2. Surdyk K., Knapowska-Niziołek M., Żona w cieniu męża, „Fakty UMP” 2009, nr 1, s. 17-18

3. Uniwersytet Poznański. Spis wykładów i skład na rok akademicki 1932/33, Poznań 1932.

Wykaz stron internetowych:

< https:/ / pl.wikipedia.org/wiki/Eugeniusz_Piasecki>, dostęp 4 maja 2018 r.

$<$ https: / / pl.wikipedia.org/wiki/Stanis\%C5\%82aw_Piasecki>, dostęp 4 maja 2018 r.

< https:/ / www.geni.com/ projects/Jewish-Families-of-Krakow>, dostęp 4 maja 2018 r.

10 Archiwum Szpitala Kubalonka w Istebnej, Akta personalne E. Piaseckiej-Zeylandowej, Pismo z 14.11.1952 r. z Departamentu Kadr M.Z. 